Лилия Я. Абрамчик

Grodzieński Uniwersytet Państwowy im Janki Kupały e-mail:1.abramchik@grsu.by

\title{
Становление налогов и их развитие на территории Беларуси (до января 1919 года)
}

\author{
SUMMARY \\ The Tax-making Process and the Development of Taxation System \\ on the Territories of Belarus (till January 1919)
}

From the moment of the creation of a state on the territories of Belarus, the system of taxation was also developing. At first it was quite primitive, based on the size of the population. Later on, when social and economic relations became more developed, new forms of taxation, based on the value of land, likewise developed.

In the 10-12th centuries, the taxes were collected from the territories. The treasury of the Grand Duchy of Lithuania consisted of pecuniary and non-pecuniary (natural) taxes. Since the beginning of the 17th century, more than 30 different taxes had existed. Some of the present taxes have roots in this old system.

The feature of this system is that it had an individual character. There were many reductions established, so that one may even talk about a - whole system of tax reductions.

Key words: Grand Duchy of Lithuania, taxes, natural taxes, tresaury, Lithuanian Statutes

История возникновения, функционирования налогов и развития норм налогового права на территории белорусского государства далеко не однозначна. Это связано с историческими этапами развития белорусского государства, развитием его права. Роль законов на разных этапах существования белорусского государства выполняли различные нормативные правовые акты - от „Русской правды” киевского князя Ярослава Мудрого, судебника Казимира 1468 года, Статутов Великого княжества 
Литовского 1529 г., 1566 г., 1588 г., Соборного уложения 1649 г. до ныне действующих Конституций Республики Беларусь и Налогового кодекса Республики Беларусь ${ }^{1}$.

Потребность в обеспечении денежными средствами функционирования государства существовала и существует всегда. Вопрос о возникновении налога как основного источника доходов казны государства всегда являлся актуальным и требующим изучения. Зная о том, какие виды налогов, сборов, пошлин собирались в разные периоды развития государства, можно судить об уровне развития государства, его экономическом и социальном положении.

С момента образования государства на белорусских землях начинает формироваться система налогообложения. Первоначально она представляла собой примитивное обложение населения данью, в дальнейшем, с развитием социально-экономических отношений, увеличением роли земельного фонда и других материальных ценностей начали зарождаться отдельные виды налогов.

\section{Белорусские земли в составе Древнерусского государства: формирование государственных доходов и основ бюджетной системы}

В течение IX-XI вв. экономическая и политическая жизнь западных земель осуществлялась по законам раннефеодального Древнерусского государства. Киевская Русь была раннефеодальной монархией. Возглавлял государство великий князь, которому подчинялись многочисленные удельные князья и бояре. Княжеские дружины держали в повиновении крестьян и мещан. Сохранилось вече, как орган местного самоуправления. Доходы великокняжеской казны формировались за счет дани с населения (позже - оброка), пошлин, доходов от продажи рабов, а также укладов

1 Полочкие грамоты XII - начало XVI вв. / сост. А. Л. Хорошкевич, ч. 16, Москва 1977; Cтатут Вялікага Княства Літоускага 1566 г. // Временникъ императорскаго московского общества истрій и древностей россійскіхъ, Книга 23, Москва, Въ Университетской Полиграфии, 1855 s. 200; Соборное уложение 1649 года, Текст. Комментарии: подготовка текста Л. И. Ивиной, Издательство "Наука" (Ленинградское отделение), 1987; Статут Великого княжества Литовского 1529 г.: Издательство Академии наук БССР, Минск 1960, s. 253; Статут Вялікага княства Літоўскага 1588: Тэксты. Давед. Камент./ Беларус. Сав. Энцыкл.; рэдкал.: І. П. Шамякін (гал. рэд.) і інш., Минск: БелСЭ, 1989, s. 573; Конституция Республики Беларусь от 15.03.1994 2., -№ 2875-XII (в ред. от 17.11.2004 г.) // Национальный реестр правовых актов Республики Беларусь 1999, № 1, 1/0.; Налоговый кодекс Республики Беларусь (Особенная часть): Кодекс Республики Беларусь от 29.12.2009 г., № 71-3 // Национальный реестр правовых актов Республики Беларусь 2010, № 4, 2/1623. 
с побежденных земель. В IX веке Киевский князь, объединив вокруг себя разные племена, обложил их данью. Отсюда и возникло понятие „подданные”. В то время дань была основным источником доходов. Она большей частью реализовывалась либо обменивалась на другие товары, пополнявшие княжескую казну. Это побуждало великих князей поощрять торговлю и способствовать ее развитию, охранять торговые интересы восточных славян и защищать великий водный путь „из Варяг в Греки”.

В Киевской Руси использовались различные способы сбора дани. Одним из методов сбора был повоз, когда покоренные племена везли ее сами прямо на княжеский двор. Такой повоз возили в Киев радимичи. Применяли и другой метод сбора дани наместниками - княжескими посадниками, собиралась дань с территории Древнерусского государства. Третьим способом сбора дани являлось полюдье, когда князья со своею дружиной сами собирали дань.

Изначально дань была основной формой феодальных повинностей и вносилась продуктами неземледельческого характера (грибы, мех, мед, воск, рыба и др.) и деньгами (кунами). Размер дани определялся местными обычаями. Дань собиралась с дыма, двора, плуга - то есть, единицей обложения данью было хозяйство смерда-общинника (смерды-княжеские люди из состава сельского земледельческого населения, обложенные данями). Когда князь сам отправлялся собирать дань, то получал от населения еще и „корм” натурой или деньгами и „дарь”. Поскольку князья приезжали не только собирать дань, но и чинить суд и управу, то население выходило к нему с дарами и поклонами. С годами такой порядок превратился в обычай, и дар из добровольного приношения сделался обязательным сбором, который назывался „полюдьем дарованным”2.

В этот период времени начинают развиваться пошлины (сборы). Эти сборы были вначале платой за различные услуги, оказываемые торговцам: мыто-пошлинный сбор с купцов за услуги при перевозке товаров через волоки или при упорядочении торговли на рынках через особых приставов-мытников; весче и померное - при перевешивании и измерении товаров. Позже все эти сборы приобрели значение чисто торговых пошлин.

В период распада Древнерусского государства, Полоцкое княжество обособилось одним из первых, а в конце XI - начале XII века от Киева обособились: Гродненское, Новогрудское, Волковысское, Пинское и Дубровенское княжества. Несколько позже отделилось и Туровское княжество.

2 Л. В. Алексеев, Полоцккая земля; Очерки истории Северной Белоруссии в IX-ХІІІ вв., Минск, Наука, 1966, s. 295. 
Полоцкое княжество стало основой государственности Беларуси. Расположение его вблизи водных путей (в бассейне Западной Двины, Березины, Немана), значительное количество крупных городов (Полоцк, Минск, Витебск, Друцк), развитие торговли и ремесленной деятельности способствовали его экономическим и политическим связям с другими княжествами Руси.

От населения князю поступали доходы в виде дани, полюдья „дарованного”, „корма”, продаж, уроков, сборов: мыто, весчего, померного (пошлин) и некоторых доходов. Князь предоставлял посадникам в пользование часть своих доходов: даней, судебных штрафов и пошлин.

На территории отдельных княжеств предусматривались дополнительные поборы с населения на содержание княжеских посадников и иных лиц из княжеского управления. В пределах отдельных княжеств функционировала собственная система сбора доходов в пользу князя. Так формировалась княжеская казна на уровне местного самоуправления. Сегодня можно считать эту казну прообразом местного бюджета.

Князья уже не удовлетворялись одними данями, судебными и торговыми пошлинами. Они искали себе и другие источники обогащения, которые видели во владении и эксплуатации земель.

В этот период земля, бывшая основным средством производства, стала собственностью феодалов. Верховным собственником земли являлся великий князь, который регулировал ее распределение между своими подданными, наделяя их землей за верную службу (государственную или военную).

Крупными феодальными землевладельцами стали князья и бояре, а с принятием христианства - церкви и монастыри. Княжеская дружина сделалась землевладельческим классом. Феодалы, получив землю, наделяли ею крестьян, которые попадали к нему в зависимость и вынуждены были выполнять феодальные повинности: платить дань, оброк продуктами, денежный оброк и отрабатывать барщину.

Если изначально основной формой повинностей была дань, то с ростом производительности труда, когда у крестьян стали появляться излишки продуктов, феодалы перевели их на оброк продуктами, а позже, на денежный оброк и барщину.

Таким образом, в IX-XI вв. создается в определенной степени упорядоченная, многоуровневая система формирования доходов казны государства, организационные принципы которой в дальнейшем лягут в основу создания налоговой и бюджетной систем Беларуси. 
Развитие феодальных отношений привело к укреплению феодальной знати и их стремлению к обособлению и политической независимости от Киева ${ }^{3}$.

За время нахождения в составе Древнерусского государства Белорусские земли накопили опыт государственно-общественной организации и сбора государственных доходов. В том числе следует обратить внимание, что в X-XII веках были заложены основы формирования бюджетной системы, заложены принципы распределения доходов между бюджетами, так, доходы, взимаемые на территории волостей, поступали в казну удельных княжеств, за исключением той части, которая направлялась великому князю. Тот факт, что великому князю отсылались доходы именно в виде части дани, позволяет признать существование принципа значимости в распределении государственных доходов: изначально дань была самым существенным доходным источником. При этом четко прослеживается территориальный принцип сбора доходов, который проявлялся в том, что расчеты с великокняжеской казной каждая территория (волость, город) вели самостоятельно, а за сбор налогов на вверенной ему территории отвечал княжеский наместник.

Относительная самостоятельность княжеств, широкие права в решении вопросов формирования доходов казны и их использования позволяют говорить о развитии такого понятия, как бюджетные налоговые права. К числу таковых прав местной администрации относятся права по: сбору доходов на своей территории, введению местных налогов и сборов, установлению их размеров.

Более того, между уровнями власти сложились вполне определенные отношения в распределении государственных доходов (между удельными князьями и великим князем), что заложило основы для развития в будущем принципов формирования межбюджетных отношений.

Уже в XII в. в Полоцкой Руси закладывались основы самостоятельной налоговой системы, обеспечивающей формирование бюджетов городов и княжеств. Следует отметить и то, что зарождавшаяся система налогообложения уже предусматривала налоговые льготы для стимулирования тех или иных процессов хозяйственной жизни самостоятельного государства.

3 Ibidem, s. 295. 


\section{Развитие норм налогового права в Великом княжестве Литовском}

Во второй половине XIII в. сложилось феодальное государство - Beликое княжество Литовское, в состав которого вошли белорусские, русские и украинские земли. Столицей своего государства князь Миндовг сделал город Новогрудок (при Гедемине с 1323 года столица была перенесена в Вильно), а Белорусский язык был признан в качестве государственного. Государственные акты издаются вначале на двух языках, а позже - исключительно на белорусском языке. Великий князь признавал себя представителем двух наций - литовской и белорусской, а в официальных грамотах и отношениях с соседними государствами он называл себя царем литовским и русским. XIII-XIV века считают Литовско-Белорусским периодом истории Беларуси ${ }^{4}$.

Первоначально Белорусские земли находились на положении автономных удельных княжеств и получали от великих князей привилеи, особо подтверждающие права, дарованные всему великому княжеству. Во главе их стояли члены литовского великокняжеского рода или местные князья, попавшие в зависимость от великого князя литовского.

Удельная эпоха в Великом княжестве Литовском характеризуется упрощенным вариантом построения взаимоотношений между великокняжеской властью и удельными княжествами по поводу формирования доходов государственной казны.

Нас в большей степени интересует развитие норм налогового права (налоги и порядок формирования и расходования казны). Для этих целей в аппарате управления при великом князе функционировали две должности подскарбия - земского и дворного. Подскарбий земский ведал казной государства, а подскарбий дворной - непосредственно доходами и расходами великокняжеских имений. В подчинении их были многочисленные скарбники: ревизоры, сборщики налогов и иные служащие, которые занимались вопросами государственно-финансовой деятельности.

Государственная казна Великого княжества Литовского формировалась из натуральных и денежных податей и платежей. При этом уже существовало разграничение между доходами, поступающими в великокняжескую (государственную) казну, и остающимися в распоряжении отдельных землевладельцев и территорий. Часть из них носила название помещичьих, благодаря тому, что частным владельцам предоставлено было право взимать их с крестьян в свою пользу. Другая часть - наибо-

4 Белоруссия в эпоху феодализма: Сб. док. В 3 т. Акад. Наук БССР, Минск, Изд-во Акад. Наук БССР, 1959-1961, Т. 1-3. 
лее значимые доходы, относилась к общегосударственным и взималась как с государственных, так и с частновладельческих крестьян. Мы можем говорить, что в этот период четко прослеживалось деление платежей на налоговые и неналоговые, деление налогов на прямые и косвенные. Все большее их количество взималось в денежной форме. Великокняжеская казна становилась денежным фондом. А это означает, что в этот период начинает развиваться бюджетная система государства. В подтверждение этому свидетельствует тот факт, что в наиболее крупных городах при воеводах и старостах создавались особые господарские (государственные) скарбы. Главные города стягивали к себе значительные господские доходы со всех или большинства волостей. Эти доходы шли большей частью на удовлетворение местных нужд, расходовались управлением центрального города. Территории, где не было особых скарбов при воеводах и старостах, участвовали в формировании господарского скарба, передавая неизрасходованные на местах господарские доходы в казну.

Местное руководство - воеводы и старосты располагали сведениями о господарских доходах и расходах в поветах, были в курсе их хозяйственной административной и казначейской деятельности. Создаваемые в городах особые господарские скарбы являлись своеобразной городской казной, прообразом городского бюджета. Тот факт, что часть государственных доходов оставалась в распоряжении территорий и использовалась на их потребности, позволяет говорить о формировании бюджетных отношений между органами государственной власти различных уровней. Однако, эти отношения не были каким-либо образом упорядочены и четко регламентированы правом.

Тем не менее, уже обозначились принципы значимости доходных источников, подчиненности плательщиков и территориальной принадлежности, в соответствии с которыми подати либо зачислялись в число господарских доходов, либо оставлялись территориям (волостям, городам) или частным владельцам.

Деление территории на волости, поветы, воеводства упорядочило организацию сбора налогов, сборов и пошлин, способствовало осуществлению контроля за этими поступлениями. Прототипом сегодняшних финансовых органов (Министерства финансов, Министерства по налогам и сборам) являлись органы государственного местного управления в лице наместников - державцев, тивунов, старост и др., отвечавшие за сбор доходов, во главе с подскарбием земским представляли собой целую организационную систему. Как представители великокняжской власти они распоряжались доходами и осуществляли расходы в пределах поветов, волостей, могли вводить местные налоги и сборы. Это свидетельствует о том, что был выработан механизм сбора налогов (податей и плате- 
жей); значительно увеличилось количество доходных источников казны за счет развития видов налогов, сборов, пошлин.

Тот государственный и социально-экономический строй, который существовал в период ВКЛ, претерпел некоторые преобразования после объединения с Польшей и создания единого государства - Речи Посполитой. То, что Речь Посполитая являлась целостным государством - это лишь внешняя характеристика государства, так как внутри государства существовало разделение на Великое княжество Литовское и Корону Польскую. Поэтому Речь Посполитая представляла собой конфедерацию, что было закреплено в Статуте ВКЛ 1588 г. Поэтому существовало множество черт, присущих лишь ВКЛ или Польше 5 . Эти события повлекли за собой также и изменения в налоговой системе.

Так, общество на белорусских землях состояло из двух основных классов: феодально-зависимых крестьян и феодалов-землевладельцев. Вместе с тем сохранялись рабы (холопы, челядь невольная). Значительную часть населения составляли свободные люди, которые не были феодалами и не находились от них в зависимости. К ним относились мещане, евреи, татары, низшее духовенство, крестьяне-данники, а также безземельная шляхта. Феодальное общество делилось по своему правовому положению на сословия: шляхту, мещан, духовенство и крестьян. Различные платежи, подати и сборы налагались на людей, либо освобождали их от обложений в зависимости от того, к какому сословию человек относился.

В этот период огромную ценность составляла земля. Но крупные землевладельцы составляли незначительную часть от всего населения. В сельской местности крестьяне облагались государственными сборами и податями за пользование землями. Так, тяглые крестьяне, которые могли пользоваться одной волокой земли феодала должны были отрабатывать барщину 4-6 дней в неделю и платить денежный оброк - серебщину. Многие крестьяне выплачивали чинш, который взимался за аренду земли с учетом ее размеров; подводная повинность, подымное, гвалты - все это сборы с зависимого населения, которые скорее представляли собой арендную плату, нежели земельный налог, так как это население было зависимо от землевладельцев ${ }^{6}$.

Совсем иную ситуацию представляли повинности крестьян-данников, которые не были подчинены какому-либо феодалу и повинности несли только в пользу великого князя или государства. Размер повинностей определялся в зависимости от общих обязанностей, которые накладывались на деревню или волость в целом.

5 Статут Вялікага княства Літоўскага 1588: Тэксты. Давед. Камент., ор. cit., s. 573.

6 Я. А. Юхо, Кароткі нарыс гісторыі дзяржавы і права Беларусі: Вучэб. дапам./ Я. А. Юхо, Мінск, Універсітэцкае, 1992, s. 270. 
Повинности распределял между крестьянскими хозяйствами выборный старец, который считался местной служебной особой. Собранные с данников денежные и натуральные подати старцы обязаны были отвезти в казну и сдать местным представителям государственной администрации. Подати, которые собирались с крестьян-данников, имели старые названия - дякла, куница, полюдье, а также различные работы по строительству замков, мостов и др. Поэтому те подати, которые взимались со свободного населения, можно определить как земельный налог, а не арендную плату за землю, что было более характерно для зависимых крестьян. Об этом говорит и сама процедура сбора налогов специальными органами и тот факт, что средства поступали в государственную казну, а не отдельному землевладельцу.

Жители городов считались свободными и выделялись в отдельное сословие мещан. Их правовое положение определялось в зависимости от города, в котором проживал мещанин, и от его имущественного положения. Значимость города определялась его правовым статусом - обладает город магдебургским правом или специальными льготными грамотами. Мещане имели право заниматься оптовой торговлей, владеть ремесленными мастерскими, а также земельным имуществом, которое обрабатывалось зависимыми от них крестьянами. Соответственно мещане должны были со своего имущества нести воинскую службу и выплачивать подати в государственную казну.

Это свидетельствует о том, что в период Речи Посполитой в ВКЛ зародился малый бизнес, и как следствие, возник налог на недвижимость. Самым распространенным малым бизнесом ВКЛ были корчмы. Порядок открытия и содержания корчмы был строго регламентирован и отражен в Статутах ВКЛ. Так, в Статуте 1529 года, в разделе третьем „О вольностях шляхты и о расширении Великого княжества Литовского” сказано, что государственная система была направлена на отслеживание нелегальных увеселительных заведений, которые не были зарегистрированы и не платили налоги в королевскую казну ${ }^{7}$ В Статутах было указано как именно содержать корчму и какие налоги платить. Законопослушные граждане, пожелавшие открыть корчму, должны были уведомить об этом короля.

B XVI веке корчма представляла собой огромный сарай, в который заезжали вместе с телегой или верхом на лошади. Со временем вид корчмы изменился, появились отдельные помещения для постояльцев и лошадей. Соответственно владельцы должны были выплачивать налог государству за те сооружения, которые приносили прибыль ${ }^{8}$.

7 Статут Вялікага княства Літоўскага 1529 года, пад рэд. К. І. Яблонскага, Мінск, Выдаўніцтва акадэміi навук БССР, 1960, s. 254. 
В литовских метриках можно увидеть много записей о предпринимателях того времени. Учитывая транзитное положение Беларуси, содержание корчмы было выгодным и прибыльным делом, поэтому такое заведение было практически в каждом селе вдоль главных дорог. Шляхтичи, которые порой считали ведение бизнеса недостойным себя занятием, нередко строили корчму в своих владениях для последующей сдачи ее в аренду. Арендовали их преимущественно еврейские жители, не имевшие такого предубеждения против деловой жизни 9 .

Таким образом, помимо многочисленных податей и сборов в ВКЛ прослеживалось постепенное становление земельного налога и налога на недвижимость. Этому способствовало развитие товарно-денежных отношений, ведение предпринимательской деятельности, открытие ремесленных мастерских и другой деятельности свободного населения.

Для данного этапа характерно отсутствие системности в установлении налоговых платежей, а различие в объектах налогообложения указывает на то, что налоги вводились субъективно, в зависимости от потребности государя в денежных средствах, что не способствовало справедливому распределению бремени расходов по содержанию государственного аппарата среди жителей одного государства.

Исходя из этого, существующие феодальные отношения затормаживали дальнейшее развитие экономических отношений, а соответственно и налоговой системы в государстве, которая зачастую носила достаточно примитивный характер.

В феодальном государстве одновременно существовали все 4 формы феодальных повинностей, но в определенные периоды одна из них была доминирующей: дань - в IX-XI вв., оброк продуктами - в XI-XIV вв., денежный оброк в XV - первой половине XVI в., и со второй половины XVI в. - барщина.

Центральное место среди всех источников занимало статутное право. Статут ВКЛ 1588 года считается самым совершенным юридическим кодексом Европы XVI-XVII столетия. Статутное право в ВКЛ составлялось под воздействием товарно-денежных отношений и торгового капитала. Поэтому вместе с феодальными нормами, такими, как непризнание за крестьянами права собственности на землю и другие ограничения их прав, получили значительное развитие нормы, которые регулировали договор купли-продажи, залога, аренды, а также отразили ситуацию в государстве, связанную с развитием налога на недвижимость и земельного налога. В этот период развития государства налоги, пошлины, сборы зависели от

9 Придорожньй сервис в ВКЛ // СБ-Беларусь сегодня [Электронный ресурс], 2010, Режим доступа: http://www.open.by/country/21741. Дата доступа: 21.01.2011. 
правового положения физического лица. Самым привилегированным сословием являлась шляхта, которая была освобождена от выплаты податей и повинностей, за исключением военной службы и податей на войну. Правоспособность простых свободных людей в феодальном обществе не была равной. Например, мещане больших городов пользовались более широкими правами, чем свободные люди, которые жили в деревнях или маленьких городах. Зависимые крестьяне имели ограниченную правоспособность, поскольку обладали правом свободно распоряжаться недвижимым имуществом.

В статуте были закреплены нормы, связанные с налогом на недвижимость и земельным налогом. Это проявилось в том, что характерной чертой феодального права собственности и владения было то, что собственник земли либо недвижимого имущества был обязан нести государственные повинности, которые были присущи этой недвижимости либо земле. Было закреплено также, что при переходе права собственности к другой особе эти повинности переходили вместе с недвижимостью. Например, как указывает в своих работах Я. А. Юхо, шляхтич или мещанин, который купил боярскую либо крестьянскую землю, если он не получил до этого освобождения от повинности, выплачивал те повинности, которые выплачивал его предшественник ${ }^{10}$.

Эти факты свидетельствуют также о том, что в некоторых ситуациях имело место продажа земли простыми людьми, это считалось законным явлением по грамоте 1581 года, а уплата повинностей не зависела от фактического собственника земли и не определялась его статусом.

В феодальном праве очень близко к праву собственности было право владения „держания”. Держание при определенных обстоятельствах могло перейти в собственность. Например, при владении недвижимым имуществом более 10 лет оно могло стать собственностью, а соответственно и облагаться установленным государством налогом на недвижимость.

В Великом княжестве Литовском и Речи Посполитой были установлены платежи в пользу государства, феодалов и церкви. Государственные крестьяне платили те же денежные платежи и натуральные, что частные и церковные. До начала XVII века в ВКЛ было более 30 различных налогов и обязанностей.

Характерной особенностью развития норм налогового права является индивидуализация налогов, установление льгот и льготных режимов. Так, в XVIII веке центральная власть неоднократно принимала постановления, по которым население городов, в виду их разорения во время войн, частично либо полностью освобождалось на определенный срок от

10 Я. А. Юхо, Кароткі нарыс гісторьі дзяржавы і права Беларусі, ор. cit., s. 270. 
уплаты налогов. По постановлению Варшавского сейма в 1661 году мещане Лиды, Могилева, Ошмян были на четыре года освобождены от всяких обложений, за исключением соляной пошлины и мыта.

Для сельской местности характерными были барщина и повинности крестьян, как частновладельческих, так и государственных (королевских).

Повинности крестьян королевских имений в ВКЛ составляли арендная плата, государственные подати и сборы:

- чинш взимался за аренду земли от 5 до 192 злотых с учетом размера земли (1981 до 4153 руб. в зависимости от количества земли);

- подорожчина (подводная повинность) давать в год 3-4 раза подводы или уплатить 18-24 злотых;

- барщина от 4 до 6 дней в неделю либо уплата денег за день барщины от 1 до 6 злотых;

- подымное от 6 до 8 злотых;

- гвалты от 3 до 12 дней в году ${ }^{11}$.

Данные налоги просуществовали до трех разделов Речи Посполитой. В результате многонациональное славянское государство прекратило свое существование, а территория Беларуси в конце XVIII века вошла в состав Российской империи.

Таким образом, уже в статуте ВКЛ 1588 года наблюдается закрепление норм, регулирующих взимание таких налогов, как налог на недвижимость и земельного налога.

Присоединение восточных районов Беларуси к России в 1772 году вызвало необходимость внести изменения в порядок рассмотрения дел в Главном суде. „По соймовому постановлению 1775 года Главный суд должен был проводить свои сессии вместо Вильни, Менска и Новогрудка, только в Вильно и Гродно". Наиболее значительные изменения в праве произошли с принятием 3 мая 1791 года Конституции, в которой были отражены прогрессивные положения, касающиеся основных отраслей права, в том числе и налогов ${ }^{12}$.

11 Статут Вялікага княства Літоўскага 1588. Тэксты. Даведнік Каментарыі, op. cit., s. 576.

12 Л. Я. Абрамчик, Становление и развитие конституционных норм налогового права на территории Республики Беларусь / Л. Я.Абрамчик // Вестник ГрГУ им. Я. Купалы Серия 4. Правоведение, 2010, № 4 (105), s. 20-28. 


\section{Беларусь в составе Российской империи}

На территории Беларуси неоднократно изменялось административно-территориальное деление, пока, наконец, не было учреждено в 1801 г. пять губерний, которые и просуществовали вплоть до революции 1917 г.

После трех разделов Речи Посполитой в 1795 году белорусские земли вошли в состав Российской империи. На присоединенные земли было распространено административно-территориальное деление на губернии и уезды. Исходя из реформы 1802 года, на территории Беларуси создавалось пять губерний: Витебская, Могилевская, Минская, Виленская и Гродненская. На них соответственно распространялась новая система налогообложения.

После вхождения в состав Российской империи население, как и прежде, делилось на четыре сословия: шляхту, крестьян, духовенство и мещан. В соответствии с „Жалованной грамотой” белорусская шляхта не платила налогов.

В белорусских губерниях была учреждена система местных органов власти и управления, предусмотренная законом „Учреждения для управления губерний Всероссийской империи" 1775 года. Вместе с тем царское правительство вынуждено было пойти на определенные уступки местному дворянству, шляхте, восстановив в 1796 г. действие Статута 1588 г., некоторые прежние названия (поветы вместо уездов), должности (поветовый маршал, подкоморий, поветовый хоружий и др.) и судебные органы, внеся лишь некоторые изменения.

Следует обратить внимание и на тот факт, что в пяти губерниях Беларуси по-разному взимались налоги (повинности) с временно-обязанных крестьян.

В Витебской и Могилевской губерниях была установлена барщина в размере 40 мужских и 30 женских дней в году за высший душевой надел; в Виленской, Гродненской и Минской губернии - не более 23 дней в году. Разграничивался и денежный оброк: 8 рублей в год за высший душевой надел в Витебской и Могилевской губернии и не выше 3 рублей с десятины в Виленской, Гродненской и Минской губернии. Были установлены казенные, земские и мирские повинности:

- подушная подать;

- сбор на обеспечение продовольствия;

- земские сборы;

- сбор на заготовление окладных листов по податям и сборам;

- рекрутская повинность;

- сбор на устройство и поддержание церквей; 
- сбор на заведование сельских училищ;

- сбор на содержание общественного управления;

- сбор на содержание сельских запасных магазинов;

- сбор на содержание и исправности проселочных дорог, знаков и т.д.;

- сбор на содержание караулов в деревнях и другие.

В 1802 году манифестом Александра I было создано Министерство финансов, одной из задач которого было определение налоговой политики. Налоги оставались главным источником доходов, их было достаточно большое количество, но основным прямым налогом была подушная подать. Однако, с постепенным зарождением капиталистических отношений в Российской империи (белорусских землях) коренным образом меняется система налогообложения. Говорить о том, что земельный налог, налог на недвижимость, в этот период развития Беларуси, не существовали, нельзя, так как ко второй половине XIX века значение поземельного налога в доходах государства относительно уменьшилось в результате введения новых видов налога, но не утратило своего значения для бюджета. Поземельный налог падал на чистый доход с земли.

В 1875 году в бюджете Российской империи (куда входила и Беларусь) появился новый „государственный поземельный” налог, образовавшийся в результате реформы существовавшего с 1853 года государственного земского сбора. Обложению государственным поземельным налогом подлежали все земли, облагаемые на основе Устава о земских повинностях местными сборами, кроме казенных земель. Общая сумма налога с каждой губернии и области определялась умножением общего числа десятин подлежащей обложению земли на средний по губернии или области оклад налога с десятины удобной земли и леса, утверждаемый в законодательном порядке. Оценка доходов с земли для их правильного обложения осуществлялась путем кадастра. Производился кадастр в период с 1843 по 1856 год с целью определения доходов казенных селений от земель, промыслов, мирских неземельных оброчных статей и лесов. Чинами кадастровых отрядов, прежде всего, производилось определение площади земель, местных различий почв по названию, качеству, главнейшим возделываемым культурам и среднему урожаю с каждого рода почвы. На основании частных таблиц составлялась общая сводная таблица урожая для губернии, а также определялся валовой доход, из которого исключались издержки производства и получали чистый доход с десятины пахотных, сенокосных и огородных земель, по каждому различию почвы, с которого и определялся оклад оброчной подати ${ }^{13}$.

13 С. И. Иловайский, Подомовой налог. Его возникновение и современный характер. Квартирный налог. Русский налог на недвижимость в городах, посадах и местечках. Обложение стро- 
В 1859 году была издана новая инструкция для оценки казенных земель министерством государственных имуществ. В соответствии с инструкцией при оценке угодья разделялись на 5 классов:

- пахотные земли;

- сенокосы, выгоны, выпуски и пастбища;

- земли под садами и ценными культурами, возделываемыми на продажу и усадьбы.

Платежи за землю зависели от статуса крестьян, которым принадлежали земли и угодья, и срока, на который выделялись эти земли. Так, по Высочайшему указу от 24 ноября 1866 года земли и угодья, находившиеся в пользовании у государственных крестьян, были оставлены за сельскими обществами в наделы, причем выданы были им на землю документы на право владения с определением неизменного в течение 20 лет платежа за землю государственной оброчной подати.

Законом от 12 июня 1886 года оброчная подать была преобразована в выкупные платежи крестьян за землю, которые вместе с мирскими сборами составляли основные земельные доходы бюджета Российской империи.

Налогообложение недвижимости. Видом обложения недвижимых имуществ являлся подомовый налог. Этот налог стал практиковаться позднее поземельного, с которым он был прежде слит и из которого он постепенно выделился в самостоятельный налог. Возникновение подомового налога в виде самостоятельной формы обложения относится к тому времени, когда городская жизнь уже достигла известной степени развития. В 1863 году мещане были освобождены от подушной подати и облагались налогом на недвижимость. Налогу подлежали:

- все недвижимые имущества, составляющие частную собственность;

- из числа принадлежащих земству, городам, духовным ведомствам (как христианских, так и нехристианских исповеданий), благотворительным и ученым обществам и установлениям и учебным заведениям, те недвижимые имущества или те их части, которые посредством отдачи их внаем, приносят доход.

Налог на недвижимость не взимался:

- с имущества, которое содержалось непосредственно за счет государственного казначейства;

- с имущества, находящегося в заведывании Кабинета Его Императорского Величества;

ений в Австрии, Венгрии, Пруссии, Италии, Франциии и Англии / С. И. Иловайский // Учебник финансового права [Электронный ресурс], 2005. Режим доступа: http://www.allpravo.ru/ librarv/doc4396p0/instrum4397/item4422.html. Дата доступа: 27.12.2011. 
- с принадлежащих Удельному ведомству зданий, в тех их частях, которые заняты под помещение Главного управления уделов и удельных округов. Законодательно было закреплено распределение налога на недвижимость между губерниями.

И если до 1830 г. на территории Беларуси действовал Статут 1588 г., то затем это функционирование было отменено, и на белорусские губернии стало распространяться общее российское законодательство с некоторыми оговорками, изъятиями и т.д. Такое положение дел в области права сохранялось до создания 1 января 1919 г. Советской Социалистической Республики Беларусь, как суверенного государства.

Таким образом, после вхождения белорусских земель в состав Российской империи произошли значительные изменения не только в социально-экономическом положении, но и в системе налогообложения.

Выводы: Изучив этапы становления и развития налогов и механизма их сбора на территории Беларуси в IX-XX веках, можно сделать следующие выводы:

1. X-XII вв. были заложены основы формирования бюджетной системы и принципы распределения доходов между бюджетами. Великому князю отсылались доходы в виде части дани, собираемой в княжестве. Прослеживается территориальный принцип сбора доходов. Расчеты с великокняжеской казной волости и города вели самостоятельно. Княжеский наместник отвечал за сбор налогов на вверенной ему территории.

Княжества имели широкие права в решении вопросов формирования доходов казны, и их использования свидетельствуют о развитии такого понятия, как бюджетные, налоговые права. К числу таковых прав местной администрации относились права: по сбору доходов на своей территории; введению местных налогов и сборов, установлению их размеров.

2. В период нахождения Беларуси в составе Великого княжества Литовского продолжают развиваться налоги, сборы. Государственная казна Великого княжества Литовского формировалась из натуральных и денежных платежей. Для своевременного формирования казны в аппарате управления при великом князе функционировали две должности подскарбия - земского и дворного. В подчинении их были многочисленные скарбники: ревизоры, сборщики налогов и иные служащие, которые занимались вопросами государственно-финансовой деятельности.

В этот период времени формировались и финансовые органы, сегодня это: Министерство финансов, Министерство по налогам и сборам.

В Великом княжестве Литовском и Речи Посполитой были установлены платежи в пользу государства, феодалов и церкви. Государственные 
крестьяне платили те же денежные платежи и натуральные, что частные и церковные. До начала XVII века в ВКЛ было более 30 различных налогов и обязанностей, в том числе и появившиеся нормы, довольно схожие с сегодняшними - земельным налогом и налогом на недвижимость.

Характерной особенностью развития норм налогового права является индивидуализация налогов, установление льгот и льготных режимов.

3. После вхождения Беларуси в состав Российской империи неоднозначно взимались налоги на всей ее территории. Особенностью этого периода налогообложения является то, что на западной части Беларуси продолжали действовать нормы статута ВКЛ 1588 года.

В пяти губерниях Беларуси по-разному взимались налоги (повинности) с временно-обязанных крестьян. В Витебской и Могилевской губерниях была установлена барщина в размере 40 мужских и 30 женских дней в году за высший душевой надел; в Виленской, Гродненской и Минской губернии - не более 23 дней в году. Разграничивался и денежный оброк: 8 рублей в год за высший душевой надел в Витебской и Могилевской губернии и не выше 3 рублей с десятины в Виленской, Гродненской и Минской губернии. Были установлены казенные, земские и мирские повинности.

В этот период времени взимание государственного поземельного налога осуществлялось со всех земель. Оценка доходов с земли для их правильного обложения осуществлялась путем кадастра, который производился в период с 1843 по 1856 годы. В 1863 году мещане были освобождены от подушной подати и платили налог на недвижимость, был определен перечень имущества, которое не подлежало налогообложению.

\section{Библиография}

Абрамчик Л. Я., Становление и развитие конституционных норм налогового права на территории Республики Беларусь / Л. Я. Абрамчик // Вестник ГрГУ им. Я. Купалы Серия 4. Правоведение, 2010, № 4 (105).

Алексеев Л. В., Полоцкая земля; Очерки истории Северной Белоруссии в IX-XIII вв., Минск, Наука, 1966.

Белоруссия в эпоху феодализма: Сб. док. В 3 т. Акад. Наук БССР, Минск, Изд-во Акад. Наук БССР, 1959-1961, Т. 1-3.

Иловайский С. И., Подомовой налог. Его возникновение и современный характер. Квартирный налог. Русский налог на недвижимость в городах, посадах 
и местечках. Обложение строений в Австрии, Венгрии, Пруссии, Италии, Франции и Англии / С. И. Иловайский // Учебник финансового права [Электронный ресурс]. 2005. Режим доступа: http://www.allpravo.ru/librarv/doc4396p0/instrum4397/item4422.html. Дата доступа: 27.12.2011.

Конституция Республики Беларусь от 15.03.1994 г. № 2875, -ХІІ (в ред. от 17.11. 2004 г.) // Национальный реестр правовых актов Республики Беларусь, 1999, № 1, 1/0.

Налоговый кодекс Республики Беларусь (Особенная часть): Кодекс Республики Беларусь от 29.12.2009 г. №71-3 // Национальный реестр правовых актов Республики Беларусь, 2010, № 4, -2/1623.

Полоцкие грамоты XII - начало XVI вв. / сост. А. Л. Хорошкевич, Москва 1977, ч. 1 .

Придорожный сервис в ВКЛ // СБ-Беларусь сегодня [Электронный ресурс], 2010. Режим доступа: http://www.open.by/country/21741. Дата доступа: 21.01.2011.

Соборное уложение 1649 года. Текст. Комментарии: подготовка текста Л. И. Ивиной, “Наука” (Ленинградское отделение), 1987.

Статут Вялікага княства Літоўскага 1588: Тэксты. Давед. Камент. / Беларус. Сав. Энцыкл.; рэдкал.: І. П. Шамякін (гал. рэд.) і інш.б Мінск, БелСЭ, 1989.

Статут Вялікага Княства Літоўскага 1566 г. // Временникъ императорскаго московского общества истрій и древностей россійскіхъ, Книга 236 Москва, Въ Университетской Полиграфии, 1855.

Статус Вялікага княства Літоўскага 1529 года / пад рэд. К. І. Яблонскага, Мінск, Выдаўніцтва акадэміі навук БССР, 1960.

Юхо Я. А., Кароткі нарыс гісторыі дзяржавы і права Беларусі: Вучэб. дапам. / Я. А. Юхо, Мінск: Універсітэцкае, 1992. 